Website: https://hipotenusa.iainsalatiga.ac.id/index.php/hipotenusa/index

Fatikha Hanum Islahia, Dyana Wijayanti*, Nila Ubaidah

\title{
Study of Theory and Technology of Exponential Function in Senior High School based on Practseology Organization
}

\author{
Fatikha Hanum Islahia ${ }^{1}$, ${ }^{2}$ Dyana Wijayanti ${ }^{2}$, Nila Ubaidah ${ }^{3}$ \\ 1,2,3 Program Studi Pendidikan Matematika Universitas Islam Sultan Agung Semarang, Indonesia. \\ E-mail: fatikha286@gmail.com¹, dyanawijayanti@unissula.ac.id² ${ }^{2}$ nilaubaidah@unissula.ac.id ${ }^{3}$ \\ *Corresponding Author \\ DOI: https://doi.org/10.18326/hipotenusa.v2i1.26-33
}

Submission Track:

Received : 28-02-2020

Final Revision : 17-06-2020

Available onlie : 17-06-2020

\begin{abstract}
Abstrak
Tujuan penelitian ini adalah untuk mengetahui perubahan materi fungsi eksponen pada buku teks matematika kurikulum berbasis kompetensi 2004 sampai kurikulum 2013 Revisi 2017 di Indonesia pada sebuah kajian teori dan teknologi serta berdasarkan referensi model epistimologi fungsi eksponen yang memuat organisasi prakseologi. Sumber data diambil dari buku pegangan matematika kelas XII IPA untuk KBK 2004 dan KTSP 2006, buku BSE matematika kelas XII untuk Kurikulum 2013 sampai Kurikulum 2013 revisi 2016 dan buku modul matematika peminatan kelas X untuk kurikulum 2013 revisi 2017. Teknik analisis data yang digunakan peneliti dibagi menjadi 4 yaitu penyandian (coding), pengkategorian (categorizing), pembandingan (comparing), pembahasan (discussing). Hasil penelitian yang yang telah dilakukan, peneliti telah menemukan penyajian teori fungsi eksponen dengan 5 kategori inti pemahaman. Pada kajian teori terdapat buku teks matematika kurikulum 2013 revisi 2016 memiliki teori yang lebih komplek dan sesuai dengan referensi model epistemologi. Sedangkan kajian teknologi terdapat buku matematika terdapat teknologi yang lebih komples yaitu buku teks matematika kurikulum 2013 revisi 2014 terdapat teknologi bentuk pertama dan pada buku teks matematika kurikulum 2013 revisi 2017 dan buku teks matematika kurikulum 2013 revisi 2016 terdapat teknologi bentuk ketiga dan pada buku teks matematika kurikulum 2006 (KTSP 2006) terdapat teknologi bentuk ketiga.
\end{abstract}

Kata Kunci: Teori dan Teknologi, Organisasi Prakseologi, Buku Teks.

\begin{abstract}
The purpose of this study was to determine the change in exponential function material in the KBK 2004 curriculum textbooks up to the 2013 revised 2017 curriculum in Indonesia in a study of theory and technology and based on reference to the epistemological model of exponent functions containing prepsychological organisation. The data source was taken from the mathematics handbook of class XII IPA for KBK 2004 curriculum and KTSP 2006 curriculum, the BSE math class XII book for 2013 curriculum until the 2013 revised 2016 curriculum and the mathematics module specialization book for class $X$ for the 2013 revised curriculum 2017. Data analysis techniques used by researchers were divided into 4, namely coding, categorizing, comparison, discussion. The results of research that has been done, researchers have found the presentation of exponential function theory with 5 core categories of understanding. In theoretical studies, the 2013 revised 2016 curriculum mathematics textbook has a more complex theory and is in accordance with the reference epistemological models. While technology studies have math books, there are more complex technologies, namely the 2013 revised 2014 curriculum mathematics textbooks, there is the first form of technology and in the 2013 revised 2017 curriculum mathematics textbooks and the 2016 revised 2013 curriculum mathematics textbooks, there is a third form of technology textbooks and the curriculum mathematics textbooks 2006 (KTSP 2006) there is a third form of technology.
\end{abstract}

Keywords: Theory and Technology, Praxeology Organisation, Textbooks. 


\section{PENDAHULUAN}

Membentuk

struktur

dalam menggambarkan suatu konsep yang disebut sistem, dengan kajian materi tertentu telah menjadi upaya manusia dalam menyajikan teori secara matematis. Konsep matematika yang dinyatakan Chevallard (1999) yaitu dalam mengetahui perkembangan penyusunan teori pada buku teks yang dalam hal ini teori merupakan langkah dalam memberikan pemahaman pada konsep matematika, dapat menggunakan organisasi prakseologi yang didalamnya terdapat empat elemen yaitu jenis soal, teknik penyelesaian, teori, dan teknologi.

Di dunia pendidikan, penerapan konsep matematika sering menjadi permasalahan pada pembelajaran matematika. Sudut pandang ini didukung pernyataan Jannah (2018) bahwa ketika menyelesaikan masalah persamaan eskponen pada teori matematika fungsi eksponen, siswa masih belum bisa mengaitkan sifat eksponen dengan sifat persamaan eksponen. Sehingga terkait dengan permasalahan tersebut penyajian teori dan teknologi pada materi pelajaran matematika masih dirasa kurang. Dengan teori dan teknologi, siswa memiliki modal dalam menyelesaikan masalah yang ditemukan. Materi pembelajaran yang terdapat dalam bahan ajar perlu adanya kesesuaian yang jelas.

Penelitian yang dilakukan oleh Wijayanti (2015) mengharapkan bahwa dengan metode penelitian berdasarkan teori organisasi prakseologi dapat digunakan sebagai pendekatan baru dalam menganalisis buku teks atau sebagai pendekatan baru dalam memiliki buku teks. Wijayanti dan Winsløw (2017) telah menganalisis buku teks dengan menggunakan referensi model prakseologi yang fokus pada soal dan teknik penyelesaian perbandingan aritmatika. Khoridah (2018) juga melakukan penelitian pada buku teks matematika yang fokus pada jenis soal dan teknik penyelesaian pada buku teks kurikulum 2006 dan kurikulum 2013. Akan tetapi Khoridah (2018) hanya melakukan penelitian perubahan penyajian soal pada buku teks materi pola bilangan saja tanpa memberikan referensi model. Jannah (2018) juga menganalisis buku teks yang fokus pada jenis soal dan teknik penyelesaian pada fungsi eksponen pada kurikulum 2013 dengan referensi model prakseologi. Dengan adanya penelitian
Jannah (2018) tersebut, peneliti ingin melanjutkan penelitian yang masih berhubungan pada fungsi eksponen, hanya saja fokus penelitiannya yaitu teori dan teknologi pada materi fungsi eksponen dengan batasan masalah pada buku teks kurikulum 2004 hingga kurikulum 2013. Berdasarkan uraian latar belakang diatas, untuk mengetahui perubahan penyajian materi fungsi eksponen pada kurikulum 2004 hingga kurikulum 2013 revisi 2017, berdasarkan teori organisasi prakseologi peneliti mengangkat sebuah judul yaitu "Kajian Teori dan Teknologi Fungsi Eksponen SMA Berdasarkan Organisasi Prakseologi”.

Latar belakang masalah yang dipaparkan diatas, rumusan masalah yang menjadi dasar penelitian ini adalah bagaimana referensi model epistemologi materi fungsi eksponen berdasarkan organisasi prakseologi dan bagaimana perubahan teori dan teknologi materi fungsi eksponen SMA kurikulum 2004 sampai kurikulum 2013 Revisi 2017.

\section{METODE}

Pendekatan penelitian ini menggunakan pendekatan kualitatif karena peneliti ingin menggambarkan objek sesuai dengan kenyataannya. Tanpa adanya fokus penelitian ini, peneliti akan terjebak oleh banyaknya data yang diperoleh ketika terjun ke lapangan, sehingga dalam penelitian ini yang menjadi fokus penelitian adalah: 1)Sumber data yang digunakan dalam penelitian ini adalah buku teks matematika; 2)Buku teks yang digunakan untuk penelitian adalah buku teks yang diterbitkan oleh Kemdikbud pada kurikulum 2004 sebanyak 1 buku, kurikulum 2006 sebanyak 4 buku dan kurikulum 2013 sebanyak 3 buku yang dapat dilihat di www.bse.kemdikbud.co.id.; 3)Buku teks yang diteliti hanya akan berfokus pada teori dan teknologi fungsi eksponen saja yang mengesampingkan pencapaian masing-masing buku teks dalam menyajikan teori dan teknologi di setiap kurikulum; 4)Referensi model epistmologi berisi teori dan teknologi fungsi persamaan eksponen yang terprosedur berdasarkan kesesuaian pada kompetensi dasar materi; 5)Dianalisis berdasarkan teori organisasi prakseologi pada setiap buku teks. Penelitian ini tidak menggunakan tempat spesifik dalam melakukan penelitian. Oleh karena itu penelitian ini merupakan penelitian "study desk evaluation" 
Jurnal Hipotenusa, 2 (1), Juni 2020

Fatikha Hanum Islahia, Dyana Wijayanti, Nila Ubaidah

Penelitian kualitatif analisis data penelitian ini adalah 1) penyandian (coding), peneliti membaca keseluruhan transkrip untuk memperoleh informasi secara umum dari masing-masing transkrip; 2) pengkategorian (categorizing), peneliti membuat referensi model epistemologi berupa materi fungsi eksponendan divalidkan melalui validator yang telah ditentukan yaitu satu dosen FKIP Pendidikan Matematika Unissula, satu Guru Matematika SMA, dan dua teman sebaya peneliti; 3) pembandingan (comparing), peneliti membandingkan teori dan teknologi fungsi eksponen pada sumber data berdasarakan teori organisasi prakseologi pada referensi model epistemology; dan 4) pembahasan (discussing), peneliti membuat simpulan berdasarkan rumusan masalah yang dibuat.

\section{HASIL DAN PEMBAHASAN}

Pada bab ini penelitian mengasilkan 2 hasil berupa referensi model epistemologi dan perbandingan referensi model epistemologi dengan 8 buku teks yang peneliti ambil. Sebelum referensi model epistemologi terbuat, peneliti terlebih dahulu merancang teori dan teknologi fungsi eksponen berdasarkan KD materi fungsi eksponen. Penyusunan ini selanjutnya di generalisasikan menjadi referensi model epistemologi.

Peneliti membuat sendiri referensi model epistemologi berdasarkan pengetahuan, beberapa sumber buku, dan teori dan teknologi pada buku teks yang sering digunakan oleh lembaga pendidikan. Referensi model epistemologi yang peneliti bahas pada hasil penelitian ini adalah kajian teori dan teknologi dimana terdapat 2 bentuk pada kajian teori dan 3 bentuk pada kajian teknologi yang akan dibahas berikut ini. Pada kajian teknologi peneliti membahas 3 bentuk dari 5 bentuk teknologi dikarenakan batasan penelitian ini dilakukan sebab keterbatasan waktu peneliti dalam proses penelitian. Referensi model epistemologi teori dan teknologi fungsi eksponen dapat kita lihat pada bagan di bawah ini.

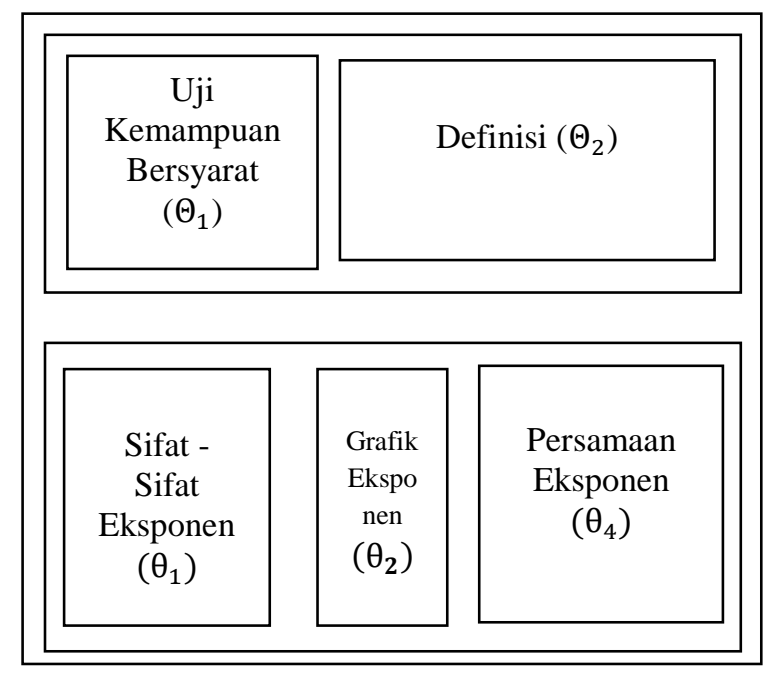

Bagan 1. Referensi Model Epistemologi Teori

$(\Theta)$ dan Teknologi $(\theta)$ Materi Fungsi Eksponen Berdasarkan Organisasi Prakseologi

Tabel 1. Teori Fungsi Eksponen Bentuk Pertama

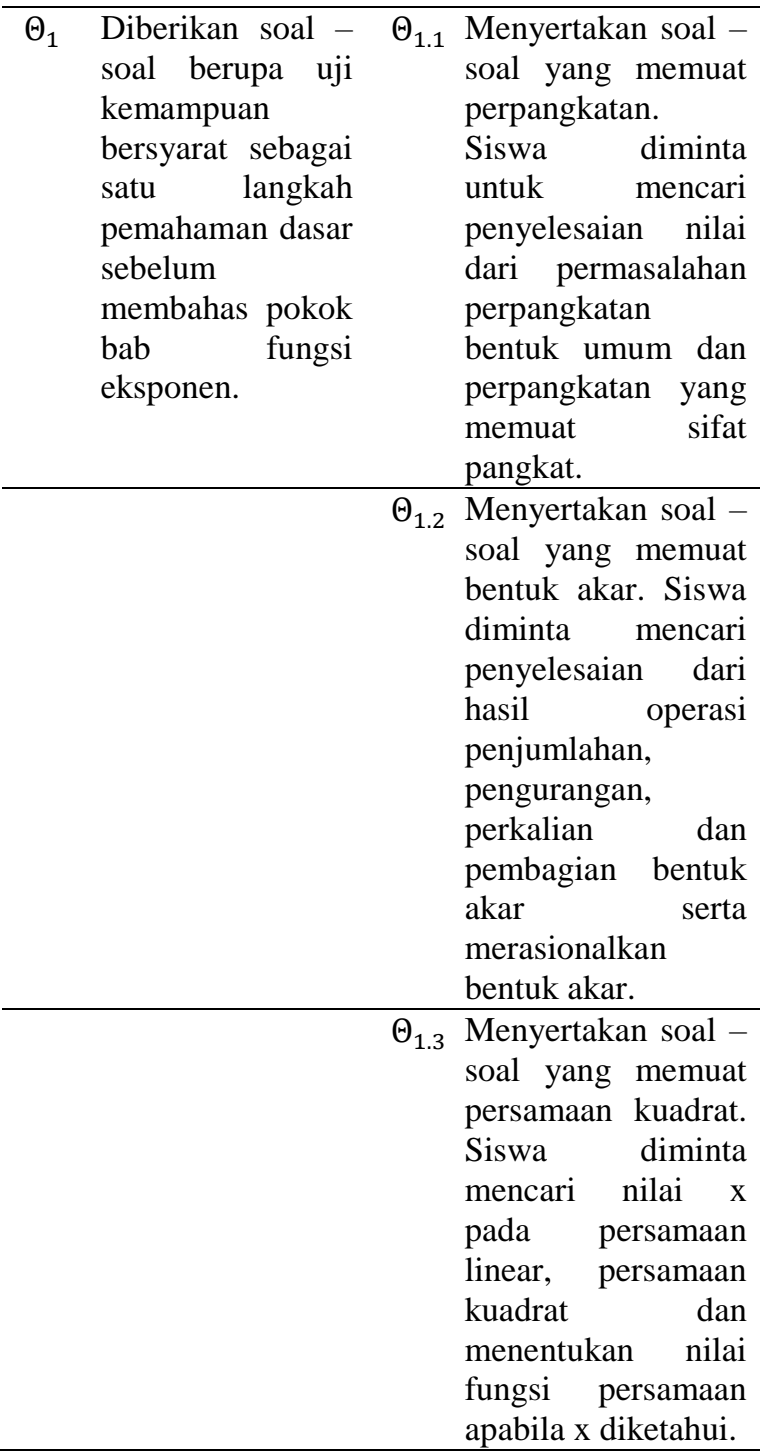


Jurnal Hipotenusa, 2 (1), Juni 2020

Fatikha Hanum Islahia, Dyana Wijayanti, Nila Ubaidah

Tabel 1 di atas menerangkan bahwa $\Theta_{1}$ merupakan referensi model epistemologi bentuk pertama teori fungsi eksponen yang memuat 3 kategori di dalamnya yaitu $\Theta_{1.1}, \Theta_{1.2}, \Theta_{1.3}$.

Tabel 2. Teori Definisi Fungsi Eksponen Bentuk Kedua

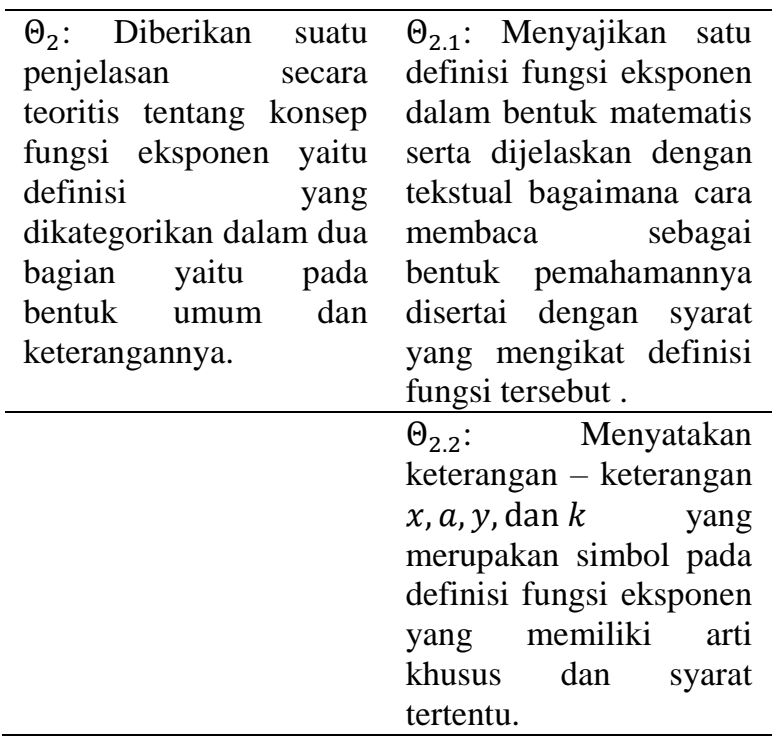

Hasil pengkategorian diatas merupakan penjelasan dari penyajian yang diciptakan peneliti tentang definisi fungsi eksponen. Dengan kajian teori di atas memenuhi 2 bentuk yang koheren dan berguna bagi siswa dalam memahami isi teori fungsi eksponen. Setelah kajian teori di atas, selanjutnya akan dibahas hasil referensi model epistemologi fungsi eksponen berdasarkan organisasi prakseologi kaitannya dengan teknologi.

Tabel 3. Teknologi Fungsi Eksponen Bentuk Pertama

\begin{tabular}{llr}
\hline$\theta_{1}$ : Diberikan sifat - & $\theta_{1.1}:$ Diberikan sifat \\
sifat fungsi eksponen & pertama $a^{0}=1$ dengan \\
yang berguna dalam & pemahaman akan adanya \\
pemahaman materi & pembuktian & sifat \\
setelah teori dikuasai. & tersebut. & \\
\hline & $\theta_{1.2}:$ Diberikan & sifat \\
& pertama $\quad a^{-m}=$ \\
& $\left(\frac{1}{a}\right)^{m}$ dengan pemahaman \\
& akan adanya pembuktian \\
& sifat tersebut. \\
\hline & $\theta_{1.3}:$ Diberikan sifat \\
& pertama $a^{m} \cdot a^{n}=a^{m+n}$ \\
& dengan pemahaman akan \\
& adanya pembuktian sifat \\
& tersebut.
\end{tabular}

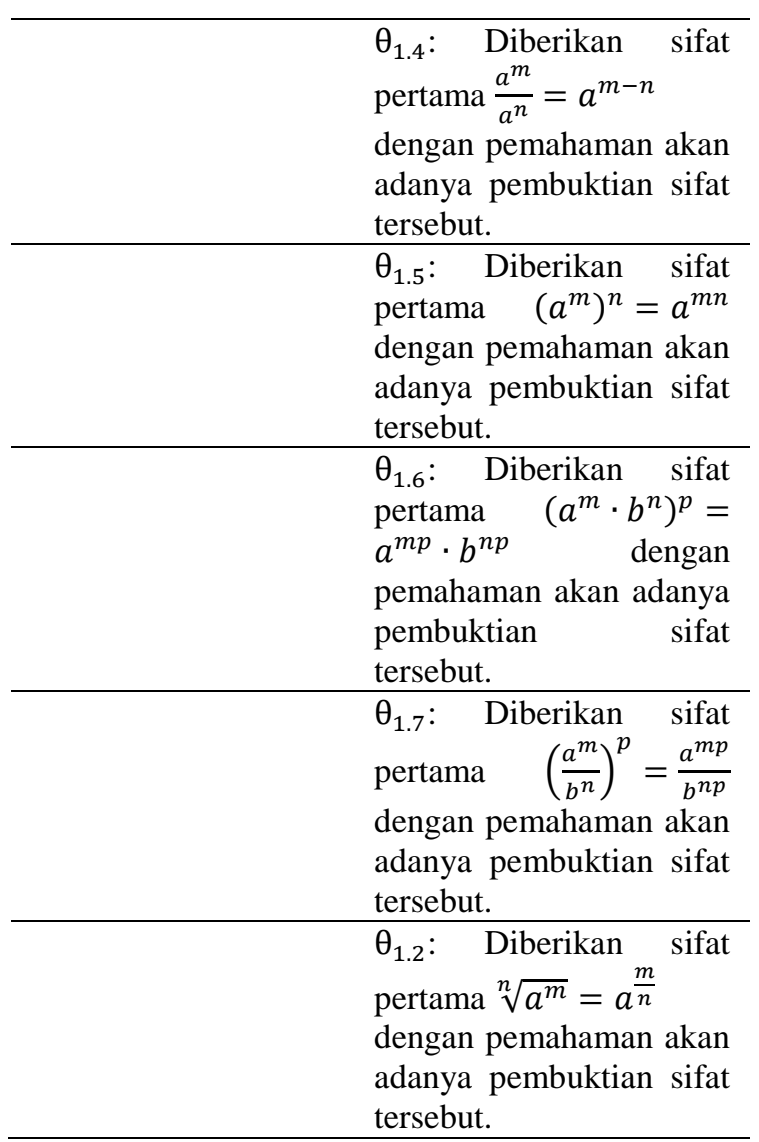

Kajian teknologi bentuk pertama pada Tabel 3 di atas akan dikategorikan seperti pada kajian teknologi pertama dengan menciptakan referensi model epistemologi teknologi fungsi eksponen bentuk kedua tentang grafik fungsi eksponen.

Tabel 4. Teknologi Fungsi Eksponen Bentuk Kedua

\begin{tabular}{|c|c|}
\hline \multirow[t]{3}{*}{$\begin{array}{lr}\theta_{2}: & \text { Diberikan } \\
\text { subbab } & \text { grafik } \\
\text { fungsi } & \text { eksponen } \\
\text { yang meliputi jenis } \\
\text { grafik r fungsi } \\
\text { eksponen, langkah } \\
\text { menggambar grafik } \\
\text { dan sifat } & - \text { sifat } \\
\text { grafik } & \text { fungsi } \\
\text { eksponen. }\end{array}$} & $\begin{array}{l}\theta_{2.1}: \text { Diberikan pemahaman } \\
\text { kaitannya dengan jenis grafik } \\
\text { fungsi eksponen yang akan } \\
\text { dipelajari yaitu grafik fungsi } \\
\text { monoton naik dan grafik } \\
\text { fungsi monoton turun. }\end{array}$ \\
\hline & $\begin{array}{l}\theta_{2.2}: \text { Diberikan penyajian } \\
\text { bagaimana menggambarkan } \\
\text { grafik fungsi eksponen pada } \\
\text { bidang Cartesius dengan } \\
\text { berbantuan tabel. }\end{array}$ \\
\hline & $\begin{array}{l}\theta_{2.3} \text { : Diberikan apa saja sifat }- \\
\text { sifat yang memenuhi pada } \\
\text { grafik fungsi eksponen. }\end{array}$ \\
\hline
\end{tabular}

Tabel di atas menjelaskan kajian teknologi fungsi eksponen bentuk kedua yaitu tentang 
penyajian grafik fungsi eksponen. Dari buku teks yang peneliti ambil terdapat grafik fungsi eksponen yang kurang tersajikan secara baik. Misalnya $\theta_{2.1}$ tidak disajikan atau $\theta_{2.1}$ disajikan bersamaan dengan $\theta_{2.3}$ secara bersamaan, sehingga siswa kurang memahami apasaja jenis grafik fungsi eksponen.

\section{Tabel 5. Jenis Teknologi Fungsi Eksponen Bentuk Ketiga}

$\theta_{3}$ : Diberikan subbab persamaan eksponen dimana terdapat 6 bentuk persamaan yang akan dibahas cara penyelesaiannya. $\theta_{3.1}$ : Diberikan persamaan $a^{f(x)}=1$ dengan $a>0$ dan $a \neq 1$ adalah himpunan yang anggotanya $x$ maka nilai $f(x)=0$.

$\theta_{3.2}$ : Diberikan penyelesaian persamaan $\quad a^{f(x)}=a^{p}$ dengan $a>0$ dan $a \neq 1$ adalah himpunan yang anggotanya $x$ sehingga $f(x)=p$.

$\theta_{3.3}$ : Diberikan penyelesaian persamaan $\quad a^{f(x)}=a^{g(x)}$ dengan $a>0$ dan $a \neq 1$ adalah himpunan yang anggotanya $x$ sehingga $f(x)=g(x)$

$\theta_{3.4}$ : Diberikan penyelesaian persamaan $\quad a^{f(x)}=a^{g(x)}$ dengan $a>0$ dan $a \neq 1$ adalah himpunan yang anggotanya $x$ sehingga $f(x)=0$

$\theta_{3.5}$ : Diberikan penyelesaian dari persamaan $h(x)^{f(x)}=$ $g(x)^{g(x)}$ dengan

kemungkinan penyelesian

$f(x)=g(x)$

a. $h(x)=1$

b. $h(x)=$

$0, f(x)$ dan $g(x)$ positif

c. $h(x)=$ $-1, f(x)$ dan $g(x)$

keduanya ganjil atau keduan $\theta_{3.6}$ : Diberikan penyelesaian persamaan eksponen $\left(a^{f(x)}\right)^{2}+B\left(a^{f(x)}\right)+C=$ 0 jika dimisalkan $a^{f(x)}=y$ maka persamaan tersebut dapat ditulis menjadi $A y^{2}+B y+C=0$. Persaman ini merupakan persamaan kuadrat dalam variabel $\mathrm{y}$.
Tabel diatas menjadi hasil pengkategorian dari bentuk ketiga teknologi fungsi eksponen yaitu persamaan eksponen. Dimana dalam hal ini referensi model epistemologi teknologi bentuk ketiga ini adalah batas hasil penelitian yang peneliti ciptakan. Tersajinya penjelasan cara penyelesaian dari tiap bentuk persamaan eksponen diharapkan siswa memahami adanya bentuk persamaan eksponen tersebut memiliki cara penyelesaian masing masing. Peneliti membatasi kajian teknologi fungsi eksponen hingga bentuk ketiga dengan alasan keterbatasan waktu penelitian. Bentuk keempat hingga seterusnya diharapkan dapat diteruskan oleh peneliti lain sesuai dengan landasan teori yang digunakan.

Tabel 6. Organisasi Prakseologi Teori dan Teknologi Buku Teks SMA Matematika IPA Berdasarkan Referensi Model Epistemologi

\begin{tabular}{ccccccccc}
\hline & \multicolumn{7}{c}{ Buku Matematika } \\
\cline { 2 - 9 } & 1 & 2 & 3 & 4 & 5 & 6 & 7 & 8 \\
\hline$\Theta_{1.1}$ & - & $\sqrt{ }$ & - & - & - & - & - & - \\
\hline$\Theta_{1.2}$ & - & $\sqrt{ }$ & - & - & - & - & - & - \\
\hline$\Theta_{1.3}$ & - & $\sqrt{ }$ & - & - & - & - & - & - \\
\hline$\Theta_{2.1}$ & $\sqrt{ }$ & $\sqrt{ }$ & - & $\sqrt{ }$ & $\sqrt{ }$ & - & - & - \\
\hline$\Theta_{2.2}$ & $\sqrt{ }$ & $\sqrt{ }$ & - & $\sqrt{ }$ & $\sqrt{ }$ & - & - & - \\
\hline \multicolumn{7}{c}{} & & \multicolumn{7}{c}{ Teknologi $(\theta)$} & & & \\
\hline$\theta_{1.1}$ & - & - & $\sqrt{ }$ & - & - & - & - & - \\
\hline$\theta_{1.2}$ & - & - & $\sqrt{ }$ & - & - & - & - & - \\
\hline$\theta_{1.3}$ & - & - & $\sqrt{ }$ & - & - & - & - & - \\
\hline$\theta_{1.4}$ & - & - & $\sqrt{ }$ & - & - & - & - & - \\
\hline$\theta_{1.5}$ & - & - & $\sqrt{ }$ & - & - & - & - & - \\
\hline$\theta_{1.6}$ & - & - & - & - & - & - & - & - \\
\hline$\theta_{1.7}$ & - & - & - & - & - & - & - & - \\
\hline$\theta_{1.8}$ & - & - & $\sqrt{ }$ & - & - & - & - & - \\
\hline$\theta_{2.1}$ & $\sqrt{ }$ & $\sqrt{ }$ & - & $\sqrt{ }$ & - & - & - & - \\
\hline$\theta_{2.2}$ & $\sqrt{ }$ & $\sqrt{ }$ & - & $\sqrt{ }$ & $\sqrt{ }$ & $\sqrt{ }$ & - & - \\
\hline$\theta_{2.3}$ & $\sqrt{ }$ & $\sqrt{ }$ & - & - & - & $\sqrt{ }$ & - & - \\
\hline$\theta_{3.1}$ & - & - & - & - & $\sqrt{ }$ & - & - & - \\
\hline$\theta_{3.2}$ & - & $\sqrt{ }$ & - & - & $\sqrt{ }$ & - & - & - \\
\hline$\theta_{3.3}$ & - & $\sqrt{ }$ & - & - & $\sqrt{ }$ & - & - & - \\
\hline$\theta_{3.4}$ & - & - & - & - & $\sqrt{ }$ & - & - & - \\
\hline$\theta_{3.5}$ & $\sqrt{ }$ & - & - & - & $\sqrt{ }$ & $\sqrt{ }$ & $\sqrt{ }$ & $\sqrt{ }$ \\
\hline$\theta_{3.6}$ & $\sqrt{ }$ & $\sqrt{ }$ & - & - & $\sqrt{ }$ & $\sqrt{ }$ & $\sqrt{ }$ & $\sqrt{ }$ \\
\hline & & & & & & & \\
\hline
\end{tabular}

Pada tabel 6 di atas terdapat penomoran 1 sampai 8 pada buku teks yang peneliti ambil dalam penelitian ini. Hal tersebut dapat dijelaskan pada keterangan berikut.

Keterangan:

1: Buku Modul Pembelajaran Matematika Peminatan dan Ilmu Pemgetahuan untuk 
SMA/MA Kelas X Semester 1, disusun berdasarkan Kurikulum 2013 Revisi 2017. Klaten: Viva Pakarindo.

2: Buku Teks Matematika Peminatan dan Ilmu Pemgetahuan untuk SMA/MA Kelas $\mathrm{X}$ Semester 1, disusun berdasarkan Kurikulum 2013 Revisi 2016. Bandung: Srikandi Empat.

3: Buku Teks Matematika untuk SMA/MA Kelas X Semester 1, disusun berdasarkan Kurikulum 2013 Revisi 2014. Jakarta: Kementrian Prndidikan dan Kebudayaan.

4: Buku Teks Matematika untuk SMA/MA Kelas XII IPA Semester 1, disusun berdasarkan Kurikulum 2006. Yogyakarta: Yudhistira.

5: Buku Teks Matematika untuk SMA/MA Kelas XII IPA Semester 1, disusun berdasarkan Kurikulum 2006. Solo: Global PT. Tiga Serangkai Pustaka Mandiri.

6: Buku Teks Matematika Aplikasi jilid 3 untuk SMA/MA Kelas XII IPA Semester 1, disusun berdasarkan Kurikulum 2006. Jakarta: Pusat Perbukuan, Departemen Pendidikan Nasional.

7: Buku Paket Pembelajaran Matematika Bilingual untuk SMA IPA Kelas XII Semester 1 \& 2, disusun berdasarkan Kurikulum Tingkat Satuan Pendidikan 2006. Bandung: CV.Yrama Widya.

8: Buku Paket Pembelajaran Matematika Bilingual untuk SMA IPA Kelas XII Semester 1 \& 2, disusun berdasarkan Kurikulum Berbasis Kompetensi 2004. Bandung: CV. Yrama Widya.

Pada bagian vertikal tabel berisi teori dan teknologi pada referensi model epistemologi. Hasil dari Analisis tersebut menyatakan teori dan teknologi pada buku teks yang peneliti ambil tidak hanya memuat satu kesamaan dengan referensi model epistemologi yang peneliti buat, namun terdapat teori dan teknologi yang memuat beberapa referensi yang berbeda. Seperti yang telah dinyatakan dalam tabel 7 terdapat 2 kajian yaitu teori dan teknologi.

Pada kajian teori ini diberikan suatu tabel perbandingan 8 buku teks SMA materi fungsi eksponen dengan referensi model epistemologi. Terdapat 5 kategori yang masing masing kategori dikelompokkan dalam 2 bentuk. Teori bentuk pertama terdapat 2 kategori yaitu $\theta_{1.1}-\theta_{1.8}$. Sedangkan pada teori bentuk kedua terdapat 3 kategori yaitu $\theta_{2.1}-\theta_{2.3}$.

Dalam hal ini banyak ditemukan pada analisis buku teks terdapat teori dan teknologi yang hanya menyatakan menyediakan beberapa kategori. Persentase teori materi fungsi eksponen pada buku teks terhadap teori memuat referensi model epistemologi peneliti dapat dilihat pada tabel 7 .

Tabel 7. PersentaseTeori Fungsi Eksponen Terhadap Referensi Model Epistemologi

\begin{tabular}{|c|c|c|c|}
\hline Buku & $\begin{array}{c}\text { Teori Yang } \\
\text { Memuat } \\
\text { RME }\end{array}$ & $\begin{array}{c}\text { Banyaknya } \\
\text { Teori Yang } \\
\text { Memuat } \\
\text { Referensi } \\
\text { Model } \\
\text { Epistemologi }\end{array}$ & Persentase \\
\hline \multirow[t]{2}{*}{1} & $\Theta_{1.1}-\Theta_{1.3}$ & - & - \\
\hline & $\Theta_{2.1}-\Theta_{2.2}$ & 2 & $40 \%$ \\
\hline \multirow[t]{2}{*}{2} & $\Theta_{1.1}-\Theta_{1.3}$ & 3 & $60 \%$ \\
\hline & $\Theta_{2.1}-\Theta_{2.2}$ & 2 & $40 \%$ \\
\hline \multirow[t]{2}{*}{3} & $\Theta_{1.1}-\Theta_{1.3}$ & - & - \\
\hline & $\Theta_{2.1}-\Theta_{2.2}$ & - & - \\
\hline \multirow[t]{2}{*}{4} & $\Theta_{1.1}-\Theta_{1.3}$ & - & - \\
\hline & $\Theta_{2.1}-\Theta_{2.2}$ & 2 & $40 \%$ \\
\hline \multirow[t]{2}{*}{5} & $\Theta_{1.1}-\Theta_{1.3}$ & - & - \\
\hline & $\Theta_{2.1}-\Theta_{2.2}$ & 2 & $40 \%$ \\
\hline \multirow[t]{2}{*}{6} & $\Theta_{1.1}-\Theta_{1.3}$ & - & - \\
\hline & $\Theta_{2.1}-\Theta_{2.2}$ & - & - \\
\hline \multirow[t]{2}{*}{7} & $\Theta_{1.1}-\Theta_{1.3}$ & - & - \\
\hline & $\Theta_{2.1}-\Theta_{2.2}$ & - & - \\
\hline \multirow[t]{3}{*}{8} & $\Theta_{1.1}-\Theta_{1.3}$ & - & - \\
\hline & $\Theta_{2.1}-\Theta_{2.2}$ & - & - \\
\hline & Jumlah & 11 & \\
\hline
\end{tabular}

Terdapat 8 buku teks yang terdiri 3 buku teks kurikulum 2013, 4 buku teks kurikulum 2006 dan 1 buku teks kurikulum 2004. Buku teks tersebut telah dijelaskan tiap keterangannya pada keterangan tabel 6 .

Tabel 7 menjelaskan umlah keseluruhan teori materi fungsi eksponen pada buku teks sebanyak 11 teori. Persentase tiap bentuk pada teori fungsi eksponen menghasilkan perbedaan dan kesamaan pada tiap - tiap buku teks. Seperti pada hasil persentase teori bentuk pertama $\left(\Theta_{1.1}-\Theta_{1.3}\right)$, buku ke-2 memuat aspek dari referensi model epistemologi sebanyak $60 \%$. Sedangkan pada buku lainnya yaitu buku ke-1, $3,4,5,6,7,8$ tidak memenuhi kategori pada bentuk pertama. Kaitannya dengan kurikulum yang digunakan tahun 2017 adalah kurikulum 2013 revisi 2017 telah mengalami pembaharuan 
Jurnal Hipotenusa, 2 (1), Juni 2020

Fatikha Hanum Islahia, Dyana Wijayanti, Nila Ubaidah

dari kurikulum 2013 revisi 2016. Sangat disayangkan bahwa teori bentuk pertama tersebut tidak termuat kembali di buku ke-1 yaitu buku teks matematika berdasarkan kurikulum 2013 revisi 2017.

Selanjutnya pada teori bentuk kedua referensi model epistemologi $\left(\Theta_{2.1}-\Theta_{2.2}\right)$ telah termuat pada buku teks ke-1, 2, 4, 5 sebanyak $40 \%$. Sedangkan pada buku teks ke-3, 6, 7, 8 teori bentuk kedua tidak disajikan. Jadi apabila kedua bentuk digabungkan persentasenya dapat disimpulkan bahwa referensi model epistemologi apabila dibandingkan dengan buku teks yang dimiliki peneliti termuat teori bentuk pertama dan kedua pada teori di buku ke-2 yang merupakan buku teks materi fungsi eksponen kurikulum 2013 revisi 2016. Dalam hal ini sangat disayangkan sekali karena berdasarkan pada penyusunan materi di buku teks siswa berdasarkan kurikulum 2013 revisi 2017 mengalai pembaharuan sehingga referensi model epistemologi teori bentuk pertama dan kedua tidak termuat. Kaitannya dengan pembelajaran juga akan terpengaruh sebab sumber belajar yang siswa gunakan tersebut tidak memfasilitasi kajian yang prosedural.

Dari pembahasan di atas dapat kita tarik simpulan bahwa referensi model epistemologi ini telah mencakup KD materi fungsi eksponen dimana dalam perbandingan dengan buku teks terdapat satu buku teks yang memuat referensi model epistemologi yaitu buku teks matematika peminatan dan ilmu pengetahuan untuk SMA/MA kelas $X$ semester 1 disusun berdasarkan kurikulum 2013 revisi 2016 diterbitkan oleh Srikandi Empat. Selanjutnya akan diberikan tabel persentase teknologi materi fungsi eksponen pada buku teks terhadap teknologi memuat referensi model epistemologi peneliti dapat dilihat pada tabel 8 .

Tabel 8. Persentase Teknologi Materi Fungsi Eksponen Pada Buku Teks Terhadap Teknologi Memuat Referensi Model Epistemologi

\begin{tabular}{cccc}
\hline & Teknologi & Banyaknya & \\
Yang & Teori Yang & \\
Memuat & Pemu \\
Memuat & Referensi \\
RME & Model & Persentase \\
& & Epistemologi & \\
\hline 1 & $\theta_{1.1}-\theta_{1.8}$ & - & - \\
\hline & $\theta_{2.1}-\theta_{2.3}$ & 3 & $19 \%$ \\
\hline & $\theta_{3.1}-\theta_{3.6}$ & 2 & $12 \%$ \\
\hline 2 & $\theta_{1.1}-\theta_{1.8}$ & - & - \\
\hline
\end{tabular}

\begin{tabular}{|c|c|c|c|}
\hline Buku & $\begin{array}{l}\text { Teknologi } \\
\text { Yang } \\
\text { Memuat } \\
\text { RME }\end{array}$ & $\begin{array}{c}\text { Banyaknya } \\
\text { Teori Yang } \\
\text { Memuat } \\
\text { Referensi } \\
\text { Model } \\
\text { Epistemologi }\end{array}$ & Persentase \\
\hline & $\theta_{2.1}-\theta_{2.3}$ & 3 & $19 \%$ \\
\hline & $\theta_{3.1}-\theta_{3.6}$ & 3 & $19 \%$ \\
\hline \multirow[t]{3}{*}{3} & $\theta_{1.1}-\theta_{1.8}$ & 6 & $35 \%$ \\
\hline & $\theta_{2.1}-\theta_{2.3}$ & - & - \\
\hline & $\theta_{3.1}-\theta_{3.6}$ & - & - \\
\hline \multirow[t]{3}{*}{4} & $\theta_{1.1}-\theta_{1.8}$ & - & - \\
\hline & $\theta_{2.1}-\theta_{2.3}$ & 2 & $12 \%$ \\
\hline & $\theta_{3.1}-\theta_{3.6}$ & - & - \\
\hline \multirow[t]{3}{*}{5} & $\theta_{1.1}-\theta_{1.8}$ & - & - \\
\hline & $\theta_{2.1}-\theta_{2.3}$ & 1 & $6 \%$ \\
\hline & $\theta_{3.1}-\theta_{3.6}$ & 6 & $35 \%$ \\
\hline \multirow[t]{3}{*}{6} & $\theta_{1.1}-\theta_{1.8}$ & - & - \\
\hline & $\theta_{2.1}-\theta_{2.3}$ & 2 & $12 \%$ \\
\hline & $\theta_{3.1}-\theta_{3.6}$ & 2 & $12 \%$ \\
\hline \multirow[t]{3}{*}{7} & $\theta_{1.1}-\theta_{1.8}$ & - & - \\
\hline & $\theta_{2.1}-\theta_{2.3}$ & - & - \\
\hline & $\theta_{3.1}-\theta_{3.6}$ & 2 & $12 \%$ \\
\hline \multirow[t]{4}{*}{8} & $\theta_{1.1}-\theta_{1.8}$ & - & - \\
\hline & $\theta_{2.1}-\theta_{2.3}$ & - & - \\
\hline & $\theta_{3.1}-\theta_{3.6}$ & 2 & $12 \%$ \\
\hline & Jumlah & 34 & \\
\hline
\end{tabular}

Tabel 8 menjelaskan jumlah keseluruhan teori materi fungsi eksponen pada buku teks sebanyak 34 teori. Persentase tiap bentuk pada teknologi fungsi eksponen menghasilkan perbedaan dan kesamaan pada tiap - tiap buku teks.

Persentase buku ke-3 memuat lebih banyak pada kategori referensi model epistemologi teknologi bentuk pertama $\left(\theta_{1.1}-\right.$ $\theta_{1.8}$ ) sebesar $35 \%$, dan untuk 7 buku lainnya tidak memuat teknologi bentuk pertama ini. Sesuai KD materi yang ada teknologi bentuk pertama $\left(\theta_{1.1}-\theta_{1.8}\right)$ ini memiliki 8 kategori dimana disajikan 8 sifat - sifat fungsi eksponen dengan pembuktiannya. Terkait dengan 8 sifat tersebut, pada buku ke-3 hanya memuat 5 sifat fungsi eksponen saja. Sehingga dapat disimpulkan pada teknologi bentuk pertama ini tidak sepenuhnya termuat di dalam buku teks ke-3 Dapat disimpulkan buku ke-3 merupakan buku yang mendekati kesesuaian dengan referensi model epistemologi yang dapat digunakan dalam pembelajaran siswa dibandingangkan dengan buku teks lainnya.

Teknologi bentuk pertama ini berupa kajian teknologi sifat - sifat fungsi eksponen yang akan digunakan dalam teknik penyelesaian 
pada teknologi bentuk ketiga yaitu persamaan eksponen. Sehingga sangat penting dalam penyusunannya yang terprosedural demi penyelesaian masalah bagi siswa.

Persentase buku ke-1 dan ke-2 pada teknologi bentuk kedua $\left(\theta_{2.1}-\theta_{2.3}\right)$ merupakan buku yang memuat lebih banyak pada kategori referensi model epistemologi daripada buku yang lainnya sebesar 19\%. Hal ini dapat dijelaskan secara berurutan tingkatan persentase tiap buku bahwa teknologi bentuk kedua dimana 3 kategori $\theta_{2.1}, \theta_{2.2}, \theta_{2.3}$ telah termuat semua pada buku ke-1 dan ke-2. Sedangan pada buku ke-4 termuat 2 kategori $\theta_{2.1}, \theta_{2.2}$ dan buku ke-6 termuat kategori $\theta_{2.2}, \theta_{2.3}$. Selanjutnya pada buku ke-5 hanya termuat kategori $\theta_{2.2}$ saja. Dapat disimpulkan bahwa referensi model epistemologi apabila dibandingkan dengan buku teks yang dimiliki peneliti termuat teknologi bentuk kedua terdapat pada buku ke-1 dan ke-2.

Referensi model epistemologi pada teknologi bentuk kedua ini yaitu grafik fungsi eksponen dimana kajian teknologi ini sesuai dengan KD materi fungsi ekponen diperlukan penyajian yang gunanya dapat dirasakan siswa dalam penyelesaian persoalan grafik.

Persentase buku ke-5 memuat lebih banyak pada kategori referensi model epistemologi teknologi bentuk ketiga $\theta_{3.1}-\theta_{3.8}$ sebesar 35\% dan. Hal ini menunjukkan bahwa adanya buku teks yang sebenarnya memiliki kajian teknologi yang memenuhi prosedural terhadap referensi model epistemologi berdasarkan organisasi prakseologi. Kategori $\theta_{3.1}, \theta_{3.2}, \theta_{3.3}, \theta_{3.4}, \theta_{3.5}$ dan $\theta_{3.6} \quad$ teknologi sepenuhnya termuat dalam salah satu buku teks yang peneliti ambil. Dapat disimpulkan bahwa referensi model epistemologi apabila dibandingkan dengan buku teks yang dimiliki peneliti termuat teknologi bentuk ketiga terdapat pada buku ke-5.

Pada kajian teknologi referensi model epistemologi yang didukung KD materi fungsi eksponen. Hal ini masih sangat disayangkan dalam menyajikan teknologi materi fungsi eksponen pada buku teks yang terbaru (buku teks matematika kurikulum 2013) dari 8 buku teks yang ada tidak termuat teknologi bentuk ketiga tersebut. Dapat disimpulkan bahwa tidak termuat sepenuhnya pada teknologi bentuk pertama hingga teknologi bentuk ketiga sesuai dengan referensi model epistemologi yang pada kajian teknologi ini penyusunannya pada beberapa buku teks siswa hanya menyediakan bentuk - bentuk teknologi saja tanpa membahasnya secara jelas bagaimana bentuk tersebut digunakan.

\section{SIMPULAN}

Dari hasil referensi model epistemlogi peneliti terdapat 2 kajian yaitu teori dan teknologi. Pada teori terdapat 2 bentuk teori yaitu teori bentuk pertama (uji kemampuan bersyarat) dan teori bentuk kedua (definisi fungsi eksponen). Sedangkan pada teknologi terdapat 3 bentuk yaitu teknologi bentuk pertama (sifat-sifat fungsi eksponen), teknologi bentuk kesua (grafik fungsi eksponen) dan teknologi bentuk ketiga (persamaan fungsi eksponen).

Selanjutnya pada perbandingan tersebut kemudian dianalisis dengan menggunakan persentase antar kedelapan buku yang berdasarkan kurikulum terdapat 3 buku pada buku kurikulum 2013, 4 buku pada kurikulum 2006 dan 2 buku kurikulum 2004. Sehingga dihasilkan simpulan yaitu pada 8 buku tersebut yang sering muncul pada buku kedua terdapat teori bentuk pertama dan kedua. Sedangkan pada teknologi yang sering muncul yaitu buku ketiga terdapat teknologi bentuk pertama dan pada buku kesatu dan kedua terdapat teknologi bentuk ketiga dan pada kelima terdapat teknologi bentuk ketiga.

\section{DAFTAR PUSTAKA}

Alhaddad, I. (2016). Perkembangan Pembelajaran Matematika Masa Kini. Delta Pi: Jurnal Matematika dan Pendidikan Matematika, 4(1),13-26.

Chevallard, Y. (1999). L'analyse des pratiques enseignantes en théorie anthropologique du didactique. Recherches en Didactique des Mathématiques, 19(2), 221-265.

Chevallard, Y., \& Bosch, M. (2012). Didactic transposition in mathematics education. In Encyclopedia of mathematics education (pp. 170-174). Springer Netherlands.

Grix, J. (2004). The foundations of research. London: Palgrave Macmillan.

González-Martín, A.S., Giraldo, V., \& Souto, A.M. (2013). The introduction of real 
Jurnal Hipotenusa, 2 (1), Juni 2020

Fatikha Hanum Islahia, Dyana Wijayanti, Nila Ubaidah

numbers in secondary education: an institutional analysis of textbooks. Research in Mathematics Education, 15(3), 230-248, doi: $10.1080 / 14794802.2013 .803778$

Jannah, A S. 2018. Transposisi Didaktik Interkoneksi Persamaan Eksponen Berdasarkan Organisasi Prakseologi. Skripsi, Universitas Islam Sultan Agung, Universitas Islam Sultan Agung.

Khoridah, H. (2018) Reposisi Organisasi Prakseologi Materi Pola Bilangan Kurikulum 2006 ke Kurikulum 2013 Revisi 2017. Skripsi, Universitas Islam Sultan Agung.

Ramda, A. H. (2017). Analisis Kesesuaian Materi pada Buku Teks Matematika Kelas VII dengan Kurikulum 2013. Phytagoras, 12(1), 12-22.

Wijayanti, D., \& Winsløw, C. (2017). Mathematical Practice in Textbooks Analysis: Praxeogical Reference Models, the Case of Proportion. REDIMAT, 6(3), 307-330. doi: 10.1783/redimat.2017.2078

Winsløw, C. (2011). Anthropological theory of didactic phenomena: Some examples and principles of its use in the study of mathematics education. Un Panorama de TAD, 117-138. 